Rika Andriyani ${ }^{1}$

Masrul $^{2}$

Moh Fauziddin ${ }^{3}$

\title{
Pengaruh Metode Becerita terhadap Kemampuan Kosakata Anak Usia Dini
}

\begin{abstract}
Abstrak
Berdasarkan hasil pengamatan di TK Taruna Pertiwi Pulau terhadap kemampuan kosakata anak belum berkembang dengan optimal. Sehingga perlu dilakukan penerapan kegiatan metode bercerita. Masalah dalam penelitian ini adalah kosakata yang dimiliki oleh anak rendah, ditandai ketika anak belum mampu menjawab pertanyaan yang diajukan. Penelitian ini bertujuan untuk mengetahui pengaruh metode bercerita terhadap kemampuan kosakata anak usia 5-6 tahun di TK Taruna Pertiwi Pulau. Sampel penelitian berjumlah 15 anak. penelitian ini menggunakan teknik sampling jenuh. Teknik pengumpulan data yang digunakan adalah observasi dan dokumentasi. Teknik analisa data menggunakan statistik dengan uji t-test dengan program SPSS 16,0. Pengujian hipotesis dilakukan dengan menggunakan uji-t dengan teknik independent T-test, diperoleh thitung sebesar 0,000 pada taraf signifikansi a $<0,005$. Dengan demikian Ho ditolak dan Ha diterima karena $0,000<0,05$. Hal ini membuktikan bahwa metode bercerita berpengaruh terhadap kemampuan koskata pada anak usia 5-6 tahun di TK Taruna Pertiwi Pulau.
\end{abstract}

\section{Kata kunci : Kemampuan Kosakata, Metode Bercerita}

\begin{abstract}
Based on the observation in TK Taruna Pertiwi Pulau Kindergarten, the child's fine vocabulary have not been optimally develoved. So it is necessary to implement Method of storytelling activities. The problem of this research was children low vocabulary, that marked when children answer the question from the story they had just heard. This study aimed to determine the influence of storytelling toward children vocabulary skills in TK Taruna Pertiwi Pulau. Sample of this research were 15 children. This study was used saturated sample technique. The data collection techniques used consisted of observation and documentation. The technique of data analysis uses statistic with t-test with programs SPSS 16,0. Hyphotesis is testing is done by using t-test with technique independent $\mathrm{T}$ test, obtained thitung 0,000 at significance level a $<0,05$, this $\mathrm{H} 0$ rejected and $\mathrm{Ha}$ accepted because of $0,000<0,05$, this proves that the storytelling method affects the vocabulary skill of children aged 5-6 years in the TK Taruna Pertiwi Pulau.
\end{abstract}

Keywords : Vocabulary Skill, Storytelling Method

\footnotetext{
${ }^{1}$ Prodi PG-PAUD Universitas Pahlawan Tuanku Tambusai, Riau, Indonesia

Email : ar1784606@gmail.com

${ }^{2}$ Prodi Pendidikan Bahasa Inggris Universitas Pahlawan Tuanku Tambusai, Riau, Indonesia

${ }^{3}$ Prodi PG-PAUD Universitas Pahlawan Tuanku Tambusai, Riau, Indonesia
} 


\section{PENDAHULUAN}

Anak usia dini adalah individu yang sedang mengalami proses pertumbuhan dan perkembangan yang sangat pesat, bahkan dikatakan sebagai lompatan perkembangan. Anak usia dini memiliki rentang usia yang sangat berharga dibanding usia-usia selanjutnya karena perkembangan kecerdasannya sangat luar biasa. Usia tersebut merupakan fase kehidupan yang unik, dan berada pada masa proses perubahan berupa pertumbuhan, perkembangan, pematangan dan penyempurnaan, baik pada aspek jasmani maupun rohaninya yang berlangsung seumur hidup, bertahap dan berkesinambungan (Mulyasa, 2012: 16).

Anak belajar bahasa untuk pertama kalinya adalah sejak lahir. Bayi yang baru lahir hanya bisa menangis untuk mengungkapkan sesuatu kepada orang dewasa. Melalui tangisan itulah bayi mengungkapkan bahasanya yaitu bahasa bayi. Misanya ketika bayi lapar, ngompol, ataupun merasa tidak nyaman ia akan menangis sebagai bahasanya.

Metode merupakan cara yang dalam fungsinya merupakan alat untuk mencapai tujuan kegiatan. Oleh karena itu, dalam memilih suatu metode yang akan dipergunakan dalam program kegiatan anak di taman kanak- kanak harus mempunyai alasan yang kuat dan faktor-faktor yang mendukung pemilihan metode tersebut.

Menurut Moeslichatoen (2004:7) metode merupakan bagian dari strategi kegiatan. Pendapat lain juga dikatakann oleh Fadillah (dalam Muyassaroh, 2015:27) bahwa metode adalah suatu cara kerja yang sistematis untuk memudahkan pelaksanaan kegiatan dalam mencapai suatu tujuan.

Berdasarkan beberapa pendapat para ahli di atas peneliti menarik kesimpulan bahwa metode adalah suatu cara yang digunakan oleh seseorang dalam suatu kegiatan baik itu dalam proses pembelajaran ataupun di luar kegiatan proses pembelajaran untuk mencapai suatu tujuan tertentu. Contohnya ketika dalam proses pembelajaran dalam mengembangkan kemampuan kosakata anak, jadi disini guru harus bisa memilih metode yang tepat dalam proses pembelajaran yang hendak dilaksanakan demi tercapainya tujuan pembelajaran itu sendiri.

Menurut Cendekia (dalam Muyassaroh, 2015:8) Metode bercerita adalah metode yang sangat baik dan disukai oleh jiwa manusia karena memiliki pengaruh yang menakjubkan untuk dapat menarik perhatian pendengar dan membuat seseorang bisa mengingat kejadian- kejadian dalam sebuah kisah dengan cepat. Pendapat lain dikemukakan oleh Moeslichatoen (2004:157) bahwa metode bercerita merupakan salah satu pemberian pengalaman belajar bagi anak TK dengan membawakan cerita kepada anak secara lisan.Cerita yang digunakan harus menarik, dan mengundang perhatian anak dan tidak terlepas dari tujuan pendidikan bagi anak TK

Dalam pendidikan pemilihan metode yang sesuai sangat diperlukan, sebab dapat berpengaruh dalam mencapai keberhasilan pembelajaran. Ada beberapa metode pembelajaran yang dapat diterapkan pada taman kanak- kanak salah satunya adalah metode bercerita. Dengan metode bercerita bisa membuat kemampuan kosakata anak lebih meningkat, peserta didik menjadi lebih aktif, lebih paham, dan bisa menguasai bahan pembelajaran yang telah diberikan oleh guru tadi dengan baik.

Menurut Munandar (dalam Sunariyanto , 2015:7) kemampuan merupakan daya untuk melakukan suatu tindakan sebagai hasil dari pembawaan dan latihan. Sedangkan menurut Robin (dalam Sunariyanto, 2015:7 kemampuan merupakan suatu kapasitas berbagai tugas dalam suatu pekerjaan tertentu. Dengan demikian, dari beberapa pendapat diatas dapat dipahami bahwa kemampuan merupakan suatu daya atau kesanggupan dalam diri setiap individu dimana daya ini dihasilkan dari pembawaan dan juga latihan yang mendukung individu dalam menyelesaikan tugasnya. 
Kemampuan potensial dalam bidang bahasa dapat diukur melalui pengetahuan kosakata. Kemampuan kosakata anak dapat berkembang seiring dengan tahapan perkembangan dan pengalamanya ketika berinteraksi dengan orang lain. Menurut Tarigan (2011 : 2) semakin kaya kosakata yang dimiliki, semakin besar pula keterampilan seseorang dalam berbahasa.

\section{METODE PENELITIAN}

Tempat penelitian ini dilaksanakan di TK Taruna Pertiwi Pulau yang terletak di Jl. Bodi Kelurahan Pulau. Waktu penelitian ini dilaksanakan pada semester ganjil Tahun ajaran 2018/2019 pada anak usia 5-6 tahun di TK Taruna Pertiwi Pulau.

Metode dalam penelitian ini merupakan metode penelitian eksperimen (Experimental Research). Penelitian eksperimen adalah penelitian yang digunakan untuk mencari pengaruh perlakuan tertentu terhadap yang lain dalam kondisi yang terkendalikan. Kondisi yang terkendalikan di maksud adalah adanya hasil dari penelitian dikonversikan ke dalam angka-angka, untuk analisis yang digunakan dengan menggunakan analisis statistik (Sugiyono, 2014: 107).

Bentuk desain eksperimen yang digunakan dalam penelitian ini adalah PreExperimental Design. Menurut Sugiyono (2014: 109) bahwa pre-eksprimental design, desain ini belum merupakan eksperimen sungguh-sungguh karena masih terdapat variabel luar yang ikut berpengaruh terhadap terbentuknya variable dependen. Bentuk pre- experimental desain penelitian yang digunakan dalam penelitian ini adalah one group pretest-posttest design, yaitu desain penelitian yang terdapat pretest sebelum diberi perlakuan dan posttest setelah diberi perlakuan. Dengan demikian hasil perlakuan dapat diketahui lebih akurat, karena dapat membandingkan dengan keadaan sebelum diberi perlakuan (Sugiyono, 2014: 110).

\section{HASIL DAN PEMBAHASAN}

TK Taruna Pertiwi beralamat di Jl. Bodi Kelurahan Pulau Kecamatan Bangkinang. Sekolah ini berdiri pada tahun 1986. Lokasi TK Taruna Pertiwi sangat strategis sehingga hal ini mendukung peserta didik untuk belajar dan berinteraksi dengan masyarakat setempat.

Analisis data dilakukan dengan teknik ststistik t-test dengan bantuan SPSS16.0. Teknik statistik t-test digunakan untuk menguji perbedaan sebelum dan sesudah perlakuan. Tujuan penelitian ini adalah untuk mengetahui pengaruh metode bercerita terhadap kemampuan kosakata pada anak usia 5-6 tahun di TK Taruna Pertiwi Pulau. Penelitian ini terdiri dua tes yaitu pretest dan posttest pada kelompok eksperimen yaitu anak usia 5-6 tahun terdiri dari 15 orang.

Gambaran tentang data penelitian secara umum dapat dilihat pada tabel deskripsi data penelitian, dimana dari data tersebut dapat diketahui fungsi-fungsi statistik secara mendasar.

Tabel Deskripsi Hasil Penelitian

\begin{tabular}{|c|c|c|c|c|c|c|c|c|}
\hline Variabel & \multicolumn{3}{|c|}{$\begin{array}{c}\text { Skor x dimungkinkan } \\
\text { (Hipotetik) }\end{array}$} & \multicolumn{4}{c|}{$\begin{array}{c}\text { Skor x yang diperoleh } \\
\text { (Empirik) }\end{array}$} \\
\hline & Xmin & Xmax & Mean & SD & Xmin & Xmax & Mean & SD \\
\hline Pretest & 8 & 15 & 21 & 1,6 & 8 & 15 & 11,4 & 2,063 \\
\hline Posttest & 8 & 15 & 21 & 1,6 & 16 & 19 & 17 & 1,195 \\
\hline
\end{tabular}

Sumber : Olahan data penelitian 
Berdasarkan rumus di atas dan melihat data empirik skor kemampuan kosakata anak didik lebih besar setelah diberikan eksperimen. Ini menandakan bahwa metode bercerita berbengaruh positif untuk meningkatkan kemampuan kosakata anak didik.

Dalam menentukan kriteria penilaian tentang hasil penelitian aktifitas anak selama proses pembelajaran dengan metode eksperimen, maka dilakukan pengelompokan atas 4 kriteria penilaian presentase menurut Suharsimi Arikunto (2010) yaitu:

Kemampuan konsep bilangan

$\mathrm{BSB}=76-100 \%$

$\mathrm{BSH}=56-75 \%$

$\mathrm{MB}=41-55 \%$

$\mathrm{BB}=<40 \%$

Gambaran Umum Kemampuan kosakata pada anak usia 5-6 tahun Di TK Taruna Pertiwi Pulau sebelum Penerapan metode bercerita (Pretest). Pengukuran terhadap kemampuan kosakata anak usia 5-6 tahun di TK Taruna Pertiwi Pulau dilakukan menggunakan observasi dengan 6 indikator kemampuan yang diberikan kepada 15 anak, berdasarkan hasil pretest dapat dilihat bahwa kemampuan kosakata pada anak usia 5-6 tahun di TK Taruna Pertiwi Pulau sebelum dilakukan.

Tingkatan Keberhasilan Indikator Kemampuan kosakata Sebelum Perlakuan (Pre-Test)

\begin{tabular}{|c|l|c|c|c|c|}
\hline No & \multicolumn{1}{|c|}{ Indikator } & $\begin{array}{c}\text { Skor } \\
\text { faktual }\end{array}$ & $\begin{array}{c}\text { Skor } \\
\text { ideal }\end{array}$ & \% & Kriteria \\
\hline 1 & $\begin{array}{l}\text { Menyebutkan kata benda, } \\
\text { nama anggota tubuh } \\
\text { seperti: kepala,tangan } \\
\text { dan kaki }\end{array}$ & 28 & 60 & 46,6667 & MB \\
\hline 2 & $\begin{array}{l}\text { Menggunakan kata kerja } \\
\text { seperti berjalan, } \\
\text { mengambil, berlari, dll }\end{array}$ & 30 & 60 & 50 & MB \\
\hline 3 & Menyebutkan warna & 33 & 60 & 55 & MB \\
\hline 4 & $\begin{array}{l}\text { Menyebutkan kelompok } \\
\text { gambar yang memiliki } \\
\text { bunyi yang sama }\end{array}$ & 24 & 60 & 40 & BB \\
\hline $\begin{array}{l}\text { Mengekspresikan } \\
\text { rasa/emosi }\end{array}$ & 29 & 60 & 48,3333 & MB \\
\hline $\begin{array}{l}\text { Membuat kalimat dengan } \\
\text { menggunakan kata } \\
\text { keterangan, tempat dan } \\
\text { keterangan waktu }\end{array}$ & 27 & 60 & 45 & MB \\
\hline Jumlah & 171 & 360 & 285 & \\
\hline & Rata-rata & & & & \\
\hline
\end{tabular}

Sumber : Olahan data penelitian

Berdasarkan tabel kriteria di atas maka dapat diketahui bahwa pada skor akhir tertinggi terdapat pada indikator ke tiga yaitu anak mampu menyebutkan warna dengan tepat dengan skor akhir 33 presentase 55\% yang berada pada kriteria $\mathrm{MB}$, anak mampu menyebutkan kata benda (anggota tubuh) dengan tepat dengan skor akhir 28 presentase $46,666 \%$ yang berada pada kriteria MB, anak mampu menggunakan kata kerja dengan

Aulad : Journal on Early Childhood, 2018 1(1), 18 - 27 
tepat dengan skor akhir 30 presentase $50 \%$ yang berada pada kriteria $\mathrm{MB}$, anak mampu menyebutkan kelompok gambar yang memiliki bunyi yang sama dengan benar dengan skor akhir 24 presentase $40 \%$ yang berada pada kriteria BB, anak mampu mengekspresikan rasa/emosi dengan benar dengan skor akhir 29 presentase 48,3333\% yang berada pada kriteria MB, anak mampu membuat kalimat dengan kata keterangan tempat dan waktu dengan skor akhir 27 presentase $45 \%$ yang berada pada kriteria MB.

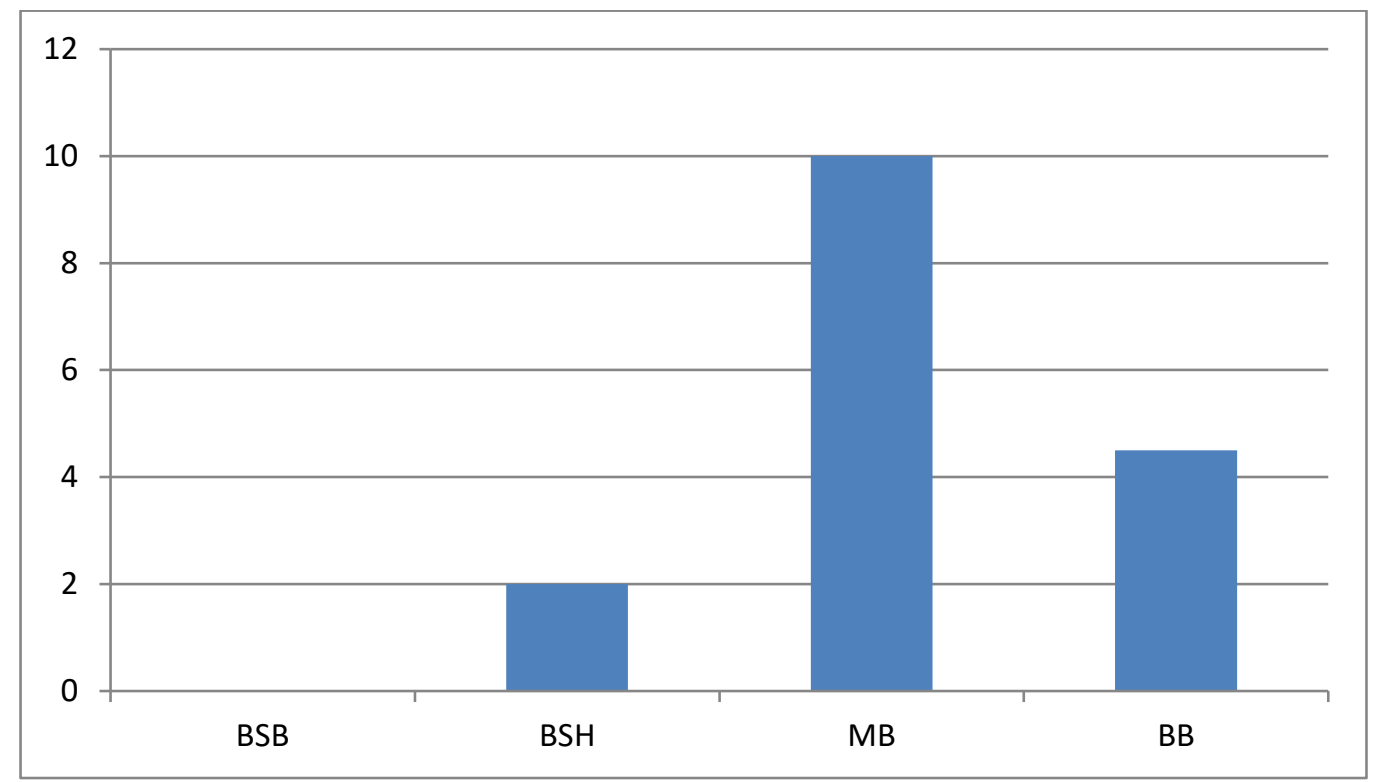

Grafik Kemampuan Kosakata Anak Sebelum Perlakuan (Pre-Test)

Sumber : Olahan data penelitia

\section{Gambaran Umum Kemampuan kosakata pada anak usia 5-6 tahun Di TK Taruna} Pertiwi Pulau Sesudah Penerapan metode bercerita (Postest)

Pengukuran terhadap kemampuan kosakata anak usia 5-6 tahun di TK Taruna Pertiwi Pulau dilakukan menggunakan observasi dengan 6 indikator kemampuan yang diberikan kepada 15 anak, berdasarkan hasil postest dapat dilihat bahwa kemampuan kosakata pada anak usia 5-6 tahun di TK Taruna Pertiwi Pulau setelah dilakukan metode bercerita dapat dilihat pada tabel dibawah ini.

\section{Tabel 4.5}

Tingkatan Keberhasilan Indikator Kemampuan kosakata Sesudah Perlakuan (Post-Test)

\begin{tabular}{|l|l|c|c|c|c|}
\hline No & \multicolumn{1}{|c|}{ Indikator } & $\begin{array}{c}\text { Skor } \\
\text { faktual }\end{array}$ & $\begin{array}{c}\text { Skor } \\
\text { ideal }\end{array}$ & \% & Kriteria \\
\hline 1 & $\begin{array}{l}\text { Menyebutkan kata benda, } \\
\text { nama anggota tubuh } \\
\text { seperti: kepala,tangan } \\
\text { dan kaki }\end{array}$ & 45 & 60 & 75 & BSH \\
\hline 2 & $\begin{array}{l}\text { Menggunakan kata kerja } \\
\text { seperti berjalan, } \\
\text { mengambil, berlari, dll. }\end{array}$ & 42 & 60 & 70 & BSH \\
\hline 3 & Menyebutkan warna & 42 & 60 & 70 & BSH \\
\hline
\end{tabular}

Aulad : Journal on Early Childhood, 2018 1(1), 18 - 27 


\begin{tabular}{|l|l|c|c|c|c|}
\hline 4 & $\begin{array}{l}\text { Menyebutkan kelompok } \\
\text { gambar yang memiliki } \\
\text { bunyi yang sama }\end{array}$ & 40 & 60 & 66,6667 & BSH \\
\hline 6 & $\begin{array}{l}\text { Mengekspresikan } \\
\text { rasa/emosi } \\
\text { Membuat kalimat dengan } \\
\text { menggunakan kata } \\
\text { keterangan, tempat dan } \\
\text { keterangan waktu }\end{array}$ & 41 & 60 & 68,3333 & BSH \\
\hline & Jumlah & 255 & 360 & 425 & BSH \\
\hline & Rata-rata & & 70,83 & BSH \\
\hline
\end{tabular}

Berdasarkan tabel kriteria di atas maka dapat diketahui bahwa pada skor akhir tertinggi terdapat pada indikator kesatu dan kelima yaitu anak mampu menyebutkan kata benda nama anggota tubuh dengan tepat dengan skor akhir 45 presentase $75 \%$ yang berada pada kriteria BSH dan anak mampu mengekspresikan rasa/emosi dengan tepat dengan skor akhir 45 presentase $75 \%$ yang berada pada kriteria $\mathrm{BSH}$, anak mampu menggunakan kata kerja dengan tepat dengan skor akhir 42 presentase $70 \%$ yang berada pada kriteria BSH, anak mampu menyebutkan warna dengan tepat dengan skor akhir 42 presentase $70 \%$ yang berada pada kriteria $\mathrm{BSH}$, anak mampu menyebutkan kelompok gambar yang memiliki bunyi yang sama dengan benar dengan skor akhir 40 presentase $66,6667 \%$ yang berada pada kriteria $\mathrm{BSH}$, anak mampu membuat kalimat dengan kata keterangan tempat dan waktu dengan skor akhir 41 presentase $68,3333 \%$ yang berada pada kriteria BSH.

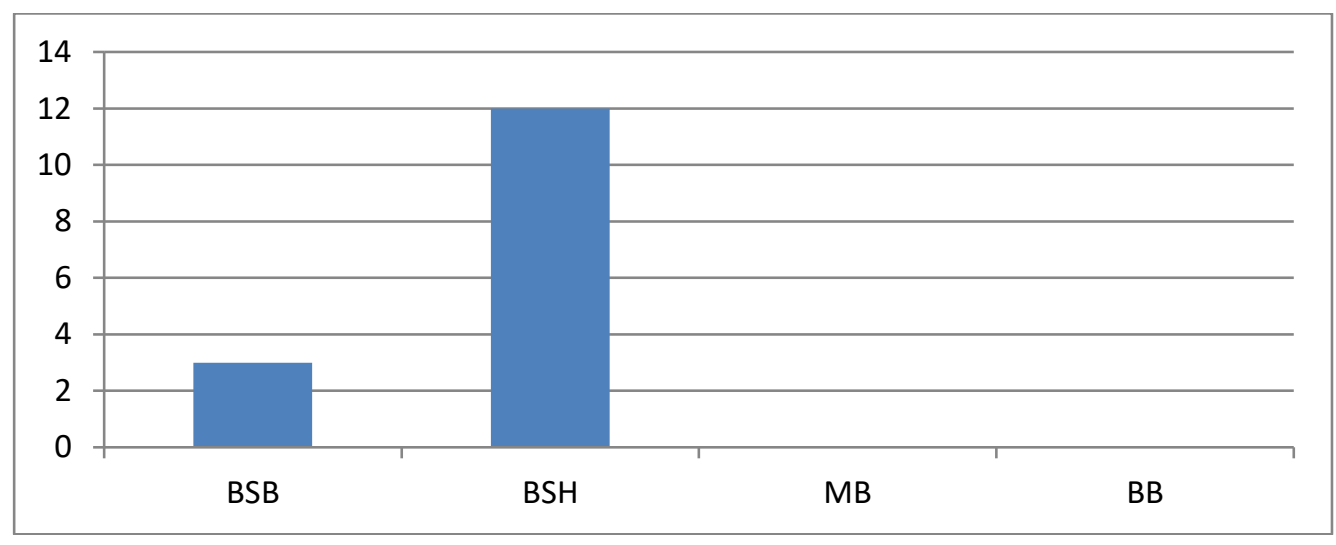

\section{Grafik Kemampuan Kosakata Anak Posttest}

\section{Perbandingan data pretest dan posttest}

Penelitian ini dilakukan menggunakan one group pretest -posttest desaign yaitu melihat hasil pretest dan posttest. Adapun hasil pretest dan posttest dapat dilihat dari tabel berikut ini. 


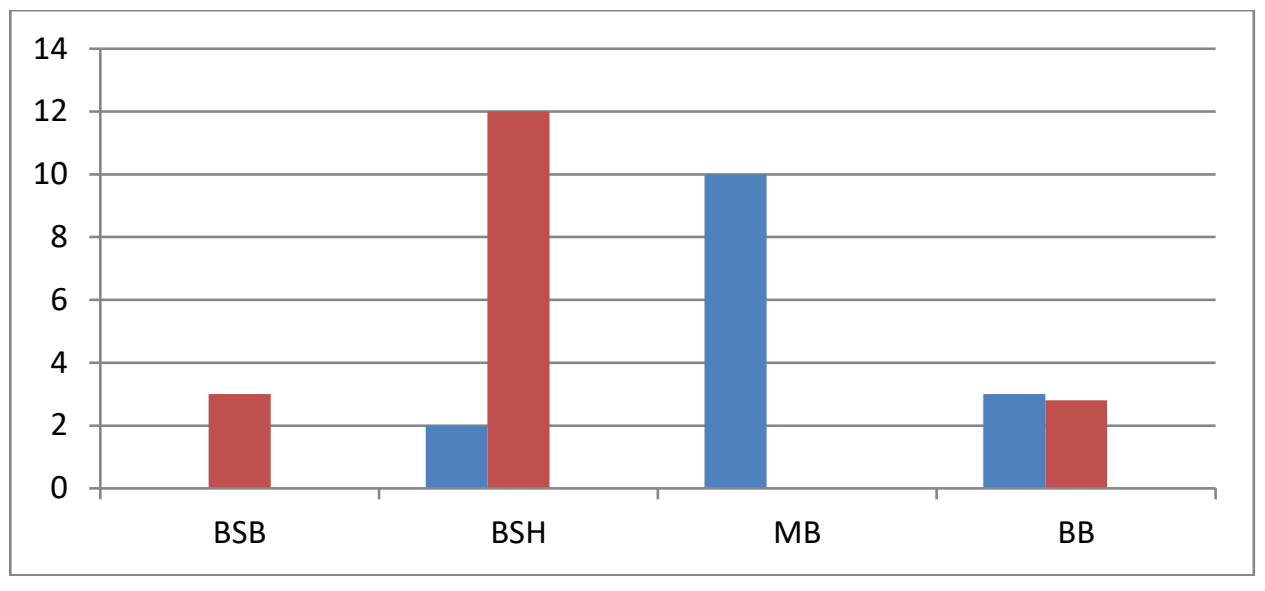

\section{Grafik Kemampuan Koskata Anak Pretest dan Posttest Metode Bercrita}

Berdasarkan kriteria maka dapat diketahui bahwa pada skor akhir tertinggi terdapat pada indikator kesatu dan kelima yaitu anak mampu menyebutkan kata benda nama anggota tubuh dengan tepat dengan skor akhir 45 presentase $75 \%$ yang berada pada kriteria $\mathrm{BSH}$ dan anak mampu mengekspresikan rasa/emosi dengan tepat dengan skor akhir 45 presentase $75 \%$ yang berada pada kriteria $\mathrm{BSH}$, anak mampu menggunakan kata kerja dengan tepat denganskor akhir 42 presentase $70 \%$ yang berada pada kriteria $\mathrm{BSH}$, anak mampu menyebutkan warna dengan tepat dengan skor akhir 42 presentase $70 \%$ yang berada pada kriteria BSH, anak mampu menyebutkan kelompok gambar yang memiliki bunyi yang sama dengan benar dengan skor akhir 40 presentase 66,6667\% yang berada pada kriteria $\mathrm{BSH}$, anak mampu membuat kalimat dengan kata keterangan tempat dan waktu dengan skor akhir 41 presentase 68,3333\% yang berada pada kriteria BSH.

Berdasarkan hasil uji normalitas dan homogenitas menunjukkan bahwa data yang diperoleh berdistribusi normal dan kedua kelas yaitu kelas eksperimen dan kelas kontrol memiliki varians data yang bersifat homogen atau memiliki varians yang sama besar. Selanjutnya dapat dilakukan pengujian hipotesis dengan menggunakan SPSS16.0 Uji hipotesis data posttest kelas eksperimen dan kontrol adalah untuk mengetahui pengaruh metode bercerita terhadap kemampuan kosakata siswa.

\section{Pembahasan Hasil Analisis Data}

Pembahasan hasil penelitian ini dilalakukan melalui hasil analisis perbandingan pada penelitian dengan jenis penelitian eksperimen terhadap variabel bebas yaitu metode bercerita $(\mathrm{X})$ dan variabel terikat yaitu kosakata anak(Y). Untuk melihat perubahan sebelum dan setelah dilakukan perlakuan (treatment) terhadap sampel. Setelah melakukan hasil perbedaan nilai sebelum (pretest) dan setelah (posttest) dari perlakuan, langkah selanjutnya yaitu melihat kemampuan kosakata anak dengan perlakuan yang telah diberikan kepada anak. Metode bercerita merupakan salah satu pemberian pengalaman belajar dengan cerita. Melalui metode bercerita anak mendapat pengalaman serta pengetahuan yang akan disampaikan melalui cerita secara lisan. Selain itu metode bercerita dapat membantu anak dalam mengembangkan dan melatih kemampuan bahasa yang anak miliki.

Metode bercerita dapat berpengaruh terhadap kemampuan kosakata anak. Dengan cerita yang dikemas dan disajikan secara menarik anak akan memiliki ketertarikan terhadap kelanjutan cerita yang diberikan. Sehingga akan ada feedback atau timbal balik antara pesan yang telah disampaikan oleh guru dalam bentuk cerita dengan apa yang diterima oleh anak. 
Metode bercerita disampaikan melalui cerita yang menarik dengan bantuan media pembelajaran. Cerita yang disampaikan harus mengandung pesan, nasihat, dan informasi yang dapat ditangkap oleh anak sehingga dapat memahami cerita serta meneladani halhal baik yang disampaikan. Melalui metode bercerita anak dapat mengembangkan kemampuan bahasannya, anak dapat menjawab pertanyaan yang diberikan oleh gurunya sehingga berpengaruh terhadap kemampuan kosakata anak.

Berdasarkan hasil analisis deskripsi kemampuan kosakata anak usia 5-6 tahun di TK Taruna Pertiwi Pulau, dilihat pada hasil pretest diperoleh jumlah nilai 171 dengan rata-rata $11,4 \%$. Skor akhir tertinggi terdapat pada indikator "anak mampu menyebutkan warna dengan tepat" dengan jumlah skor 30, indikator kemampuan ini mendapat skor tertinggi karena hampir semua anak mampu menyebutkan warna dengan benar. Kemudian skor terendah terdapat pada indikator "anak mampu menyebutkan kelompok gambar yang memiliki bunyi yang sama" sesuai dengan jumlah skor 24. Indikator ini mendapat nilai terendah dikarenakan anak belum mampu menyebutkan kelompok gambar yang memiliki bunyi yang sama dengan benar.

Pada hasil posttest atau setelah diberi perlakuan diperoleh nilai 255 dengan ratarata $17 \%$. skor akhir tertinggi terdapat pada indikator kesatu dan kelima "menyebutkan kata benda nama anggota tubuh dan mengeksperesikan rasa/emosi" dengan jumlah skor 45, indikator kemampuan ini mendapat skor tertinggi karena indikator ini diberi perlakuan. Kemudian skor terendah terdapat pada indikator keempat "menyebutkan kelompok gambar yang memiliki bunyi yang sama" dengan jumlah skor 40. Indikator ini menjadi indikator terendah sebelum diberi perlakuan .

Berdasarkan analisis pengolahan data dan hasil persentase di atas dapat di jelaskan hasil pretest anak usia 5-6 tahun di TK Taruna Pertiwi Pulau diperoleh jumlah nilai 171 dengan rata-rata 11,4 ,. Jika dilihat secara kategori perorangan sebelum diberi perlakuan maka kategori BSB sebanyak 0 orang anak dengan presentase $0 \%$, anak yang pada kategori BSH sebanyak 2 orang anak dengan presentase $13 \%$, anak yang pada kategori MB sebanyak 10 orang anak dengan persentase $67 \%$, anak yang pada kategori BB sebanyak 3 orang anak dengan presentase $20 \%$. Begitu pentingnya kemampuan kosakata bagi anak, maka anak harus distimulasi agar kosakata anak dapar berkembang sesuai usianya.

Melatih kemampuan kosakata anak dapat dilakukan dengan bantuan orang dewasa dan teman-temannya dengan kegiatan ataupun metode. Metode bercerita memungkinkan anak untuk berlatih kemampuan kosakata nya, maka tidak disadari kemampuan kosakata anak akan meningkat. Penelitian yang relevan dengan penelitian ini adalah penelitian yang dilakukan oleh Annisa Rohmatul Muyassaroh (2015) yang berjudul "Pengaruh Metode Bercerita Terhadap Kemamapuan Kosakata Dasar Anak Usia 4-5 tahun di RA Muslimat Banyumas" yang terbukti dapat mengembangkan dan meningkatkan kemampuan kosata kata anak usia 5-6 tahun dalam berkomunikasi dan menyampaikan suatu ide. Sehingga metode bercerita dapat berpengaruh terhadap kemampuan kosakata anak. Dengan cerita yang dikemas dan disajikan secara menarik anak akan memiliki ketertarikan terhadap kelanjutan cerita yang diberikan. Sehingga akan ada feedback atau timbal balik antara pesan yang telah disampaikan oleh guru dalam bentuk cerita dengan apa yang diterima oleh anak dalam mengembangkan kemampuan kosakata anak usia 5-6 tahun di TK Taruna Pertiwi Pulau.

Penelitian eksperiman ini dilakukan untuk mengetahui adanya pengaruh signifikan sebelum dan setelah diberikan perlakuan metode bercerita. Uji signifikan perbedaan ini dengan $\mathrm{t}$ statistik diperoleh thitung $=13,234$ dengan $\mathrm{Sig}=0,0000$, karena nilai sig $<0,05$ berarti signifikan. Jadi ada perbedaan perubahan kemampuan kosakata anak didik yang signifikan antara sebelum dan sesudah metode bercerita, dimana setelah 
perlakuan mempunyai perubahan lebih besar dibandingkan sebelum perlakuan.

Hal ini adanya pengaruh kemampuan kosakata dengan metode bercerita.

Berdasarkan uraian di atas, dapat disimpulkan bahwa metode bercerita berpengaruh terhadap kemampuan kosakata anak usia 5-6 tahun di TK Taruna Pertiwi Pulau.

\section{SIMPULAN}

Berdasarkan hasil penelitian yng dilakukan di TK taruna Pertiwi Pulau tentang Pengaruh Metode Bercerita Terhadap Kemampuan Kosakata Anak, maka peneliti menarik kesimpulan sebagai berikut: Kemampuan Kosakata anak usia 5-6 tahun di TK Taruna Pertiwi Pulau pada kelompok B sebelum di beri perlakuan berada pada kategori kurang, artinya kemampuan kosakata anak sebelum diberikan perlakuan kurang dan belum sesuai dengan yang diharapkan. Kemampuan kosakata anak 5-6 tahun di TK Taruna Pertiwi Pulau pada kelompok B setelah diberikan perlakuan berada pada kategori baik, artinya dengan diberikannya perlakuan berupa metode bercerita, kemampuan kosakata anak menjadi meningkat dari kategori kurang menjadi kategori baik Terdapat pengaruh yang signifikan metode bercerita terhadap kemampuan kosakata anak usia 5-6 tahun di TK Taruna Pertiwi Pulau, dimana dapat diketahui ada perbedaan berupa pengingkatan kemampuan kosakata anak didik sebelum dan sesudah pelaksanaan dengan memberikan metode bercerita.

\section{DAFTAR PUSTAKA}

Arikunto, Suharsimi. (2006). Prosedur Penelitian Suatu Pendekatan Praktik. Jakarta: PT Rineka Cipta.

Bimo. (2010). Makalah Ringkas. [Online]. Tersedia dalam: https://kakbimo.wordpress.com/makalah- ringkas/[diakses 25 Desember 2017].

Dhieni, Nurbiana dkk. (2007). Metode Pengembangan Bahasa. Jakarta: Universitas Terbuka.

Fauziddin, Mohammad. (2014). Pembelajaran PAUD. Bandung: PT Remaja Rosdakarya.

Gusmalinda, (2016).Pengaruh Media Gambar Diam Terhadap Kemampuan Berbicara Anak Uisa 5-6 Tahun Di Paud Kemuning Kecamatan Tenayan Raya Pekanbaru. Universitas Riau: Pekanbaru

Hartono. (2012). Statistik untuk Penelitian. Yogyakarta: Pustaka Pelajar.

http://webcache.googleusercontent.com/search? q=cache:i AyZ qq6jj nEJ :j urnalmahasi swa.unesa.ac.id/article/1437/19/article.pdf $\quad+\& \mathrm{~cd}=5 \& \mathrm{hl}=\mathrm{id} \& \mathrm{ct}=\mathrm{clnk} \& \mathrm{gl}=\mathrm{id}$ [Diakses 05 Januari 2018]

Kamus Besar Bahasa Indonesia, (2001). Departemen Pendidikan Nasional

Kamus Besar Bahasa Indonesia, (2001). Departemen Pendidikan Nasional

Menteri Pendidikan dan Kebudayaan Republik Indonesia. (2014) Peraturan Menteri Pendidikan dan Kebudayaan Republik Indonesia Nomor 146 Tahun 2014 Tentang Kurikulum 2013 Pendidikan Anak Usia Dini. Menteri Pendidikan dan Kebudayaan Republik Indonesia : Jakarta.

Menteri Pendidikan dan Kebudayaan Republik Indonesia. (2014). Peraturan Menteri Pendidikan dan Kebudayaan Republik Indonesia Nomor 137 Tahun 2014 Tentang Standar Nasional Pendidikan Anak Usia Dini. Menteri Pendidikan dan 
Kebudayaan Republik Indonesia : Jakarta.

Metode Bercerita Untuk Meningkatkan Kosakata Anak Usia 3-4 Tahun Pada Play Group Tunas Bangsa Mojokerto. [Online] Tersedia dalam

Moeslichatoen. (2004). Metode Pengajaran di Taman Kanak-Kanak. Jakarta: Rineka Cipta.

Mulyasa. (2012). Manajemen PAUD. Bandung:PT. Remaja Rosdakarya

Muyassaroh, Rohmatul Annisa, Jurnal. Pengaruh Metode Bercerita Terhadap Kemampuan Kosakatadasar Anak Usia 45 Tahun Di RA Muslimat Banyumas Kabupaten Pringsewu. [Diakses] Tersedia dalam http://Ejournal.xhzgs.Com/2016/09/Pendidikan-Anak-Usia-Dini/Article.Html [Diakses 30 Desember 2017]

Naibaho, Santha. (2017). Pengaruh Kegiatan Kolase Montase Terhadap Kemampuan Motorik Halus Anak Usia 56 Tahun di TK Tunas Melati Kandis, Kabupaten Siak. Univrsitas Riau: Pekanbaru

Rodiyah, Asri. (2013). Penggunaan

Sardi, N dkk. (2012). Pengaruh Pembelajaran dengan Teknik Bercerita DongengTerhadap Kemampuan Berbahasa dan Motovasi Anak Kelompok B TK Kunti II Dalung. [Online] Tersedia dalam https://media.neliti.com/media/publication s/Article. Html [Diakses 30 Desember 2017]

Sugiyono. (2012). Memahami Penelitian Kualitatif. Bandung: Angkasa.

Sugiyono. (2014). Metode Penelitian Pendidikan Pendekatan Kuantitatif Kualitatif dan R\&D. Bandung: Alfabeta.

Sujiono, Yuliani Nurani. (2009). Konsep Dasar Pendidikan Anak Usia Dini. Jakarta: PT Indeks.

Sukardi. (2012). Metodologi Penelitian Pendidikan. Jakarta: PT Bumi Aksara.

Sunariyanto. (2015). Upaya Meningkatkan Kemampuan Berbicara Anak Usia 5-6 tahun dengan Media Poster Di TK ABA Yogyakarta. [Online] Tersedia dalam http://webcache.googleusercontent.c om/search?q=cache:1c9ko2HMVbUJ journal.student.uny.ac.id/ojs/index.php/pgpaud/article/viewFile/320/292+\&cd=1 0\&hl=i d\&ct=clnk\&gl=id [Diakses 05 Januari 2018]

Tarigan, Henry Guntur. (2011). Menyimak Sebagai Keterampilan Bahasa. Bandung: Angkasa.

Tarigan. (1984). Pengajaran Kosakata. Bandung: Angkasa

Yus, Anita. (2011). Model Pendidikan Anak Usia Dini: Kencana 